\title{
Deskripsi Pemahaman Konsep Matematika Siswa Ditinjau dari Intensitas Penggunaan E-Learning Quipper Video
}

\author{
Fitrahlaelah Muh. Asri ${ }^{1, a)}$, Ruslan ${ }^{1}$, dan Asdar $^{1}$ \\ ${ }^{1}$ Jurusan Matematika, Fakultas MIPA, Universitas Negeri Makassar \\ a) fitrahlaelah@gmail.com
}

\begin{abstract}
Abstrak. Penelitian ini bertujuan untuk mendeskripsikan pemahaman konsep matematika siswa pada materi perpangkatan ditinjau dari intensitas penggunaan e-learning quipper video. Jenis penelitian ini adalah kualitatif deskriptif. Subjek pada penelitian ini dipilih secara acak masing-masing satu untuk kategori intensitas tinggi, intensitas sedang, dan intensitas rendah. Adapun teknik pengumpulan data dengan pemberian angket intensitas penggunaan quipper video, tes pemahaman konsep, dan wawancara kemudian melalui tiga tahapan analisis data yaitu kondensasi data, penyajian data, dan penarikan kesimpulan. Hasil penelitian menunjukkan bahwa pemahaman konsep matematika: (1) Subjek dengan intensitas penggunaan quipper video tinggi kurang memahami konsep pada indikator mengaplikasikan konsep atau algoritma pada pemecahan masalah. (2) Subjek dengan intensitas penggunaan quipper video sedang maтри menyatakan ulang konsep, mengklasifikasi objek menurut sifat-sifat tertentu sesuai dengan konsepnya, menggunakan dan memanfaatkan serta memilih prosedur atau operasi tertentu, mengaplikasikan konsep atau algoritma pada pemecahan masalah, memberikan contoh dan bukan contoh, menyajikan konsep dalam berbagai representasi matematis, dan mengembangkan syarat perlu atau syarat cukup dari suatu konsep. (3) Subjek dengan intensitas penggunaan quipper video rendah kurang memahami konsep pada indikator menyatakan ulang suatu konsep, memberikan contoh dan bukan contoh dari suatu konsep, dan mengembangkan syarat perlu atau syarat cukup dari suatu konsep.
\end{abstract}

Kata Kunci: pemahaman konsep, intensitas, quipper video

\begin{abstract}
This research aims to describe students' mathematics conceptual understanding understanding with topics exponential considered of the intensity of using quipper video. This type of research is descriptive qualitative. Subjects in this study were randomly selected one for the category of high intensity, one medium intensity, and one low intensity. The data collection techniques by giving intensity questionnaires use quipper video, understanding concept tests, and interviews then through three stages of data analysis, namely data condensation, data presentation, and conclusion. The results showed that understanding mathematical concepts: (1) Subjects with high intensity of using quipper video were unable to understand the concept in indicators apply concepts or algorithms to problem solving. (2) Subjects with medium intensity of using quipper video are able to restate the concept, classify objects according to certain characteristics in accordance with the concept, use and utilize certain procedures or operations, apply concepts or algorithms to problem solving, provide examples and not examples, present concepts in various mathematical representations, and develop necessary requirements or sufficient requirements from a concept.(3) subject with low intensity of using quipper video did not understand the concept in indicator restating the concept, , provide examples and not examples, and develop necessary requirements or sufficient requirements from a concept.
\end{abstract}

Keywords: concept understanding, intensity, quipper video 


\section{PENDAHULUAN}

Matematika sebagai salah satu mata pelajaran di sekolah, harus dikuasai oleh peserta didik dari jenjang sekolah dasar hingga perguruan tinggi. Hal ini dapat menandakan bahwa betapa pentingnya mempelajari matematika sejalan dengan tuntutan perkembangan zaman. Selain itu, matematika juga dapat digunakan untuk mengasah pola pikir seseorang agar dapat mengaplikasikan keterampilan yang dimiliki untuk menyelesaikan permasalahan dalam kehidupan (Rohana, 2011). Sebagai ilmu yang mengutamakan pemikiran logika, mempelajari matematika tentu mengharuskan peserta didik untuk memahami konsep-konsep matematika agar dapat memecahkan masalah yang dihadapi.

Memahami konsep matematika merupakan hal yang sangat mendasar karena pemahaman dapat membantu kemampuan lain seperti pengetahuan prosedural. Kilpatrick, Swafford, dan Findell (2001) mengungkapkan bahwa pemahaman konsep merupakan pemahaman dari suatu operasi dan relasi dalam matematika. Namun, peserta didik saat ini kurang memahami konsep-konsep matematika. Sebagaimana yang diungkapkan Russefendi (1988) bahwa terdapat banyak peserta didik yang setelah belajar matematika, tidak mampu memahami bahkan pada bagian sederhana sekalipun. Banyak konsep yang dipahami secara keliru sehingga matematika dianggap sebagai ilmu yang sukar, ruwet, dan banyak memperdayakan.

Seiring dengan perkembangan teknologi informasi dan komunikasi, pembelajaran secara elektronik (e-learning) khususnya matematika dibuat semakin menyenangkan. Sehingga peserta didik dapat dengan mudah memahami konsep dari pelajaran yang diberikan. Dengan adanya $e$ learning peserta didik dapat membangun pengetahuannya sendiri secara lebih luas dan mendalam. Apalagi dengan sistem kurikulum yang pembelajarannya berpusat pada peserta didik.

Salah satu e-learning hasil dari perkembangan teknologi informasi dan komunikasi adalah Quipper. Quipper sendiri telah berdiri sejak tahun 2010 yang dimulai dengan quipperschool berisi ringkasan materi secara tertulis dan soal-soal latihan. Hingga tahun 2015 Quipper merilis fitur terbarunya yaitu Quipper Video yang dibuat lebih menarik lagi. Sesuai dengan namanya, Quipper Video memberikan video pembelajaran secara online bagi para peserta didik kapan dan dimana pun, disertai dengan ringkasan materi dan soal-soal. Quipper video didesain khusus untuk pendidikan menengah pertama (SMP) dan pendidikan menengah atas (SMA) dengan isi materi ajar sesuai dengan kurikulum yang ada di Indonesia yaitu Kurikulum Tingkat Satuan Pendidikan (KTSP) dan Kurikulum 2013 (K-13). Selain itu Quipper video tidak hanya dapat digunakan pada perangkat komputer tapi juga dapat digunakan pada smartphone sehingga dapat diakses dimana saja.

Penerapan pembelajaran e-learning Quipper Video telah dilakukan di beberapa sekolah di Makassar. Salah satunya yaitu SMP yang peneliti jadikan lokasi penelitian telah menggunakan Quipper Video sejak tahun 2017. Pengguna Quipper Video merupakan peserta didik kelas IX, hal ini disarankan langsung oleh sekolah karena dapat membantu peserta didik dalam menghadapi Ujian Nasional. Dengan demikian, semua siswa kelas IX mempunyai akun quipper video-nya masing-masing. Peserta didik sering kali mendapatkan hasil belajar yang bervariasi disebabkan oleh banyak faktor yaitu seperti rendahnya pemahaman konsep matematika yang dimiliki. Ada kalanya peserta didik yang menggunakan Quipper Video lebih mudah memahami materi ajar. Oleh karena itu, penelitian ini bertujuan untuk mengetahui deskripsi pemahaman konsep matematika siswa ditinjau dari intensitas penggunaan E-Learning Quipper Video materi perpangkatan. 


\section{KAJIAN PUSTAKA}

\section{Pemahaman Konsep Matematika}

National Council of Teachers of Mathematics atau NCTM (2000) mengungkapkan bahwa peserta didik harus mempelajari matematika dengan pemahaman, secara aktif membangun pengetahuan baru dari pengalam dan pengetahuan awalnya. Depdiknas dalam Humedi (2017) menyatakan bahwa pemahaman konsep merupakan salah satu kecakapan atau kemahiran matematika yang diharapkan dapat tercapainya dalam pembelajaran matematika yaitu dengan menunjukkan pemahaman konsep matematika yang dipelajarinya, menjelaskan keterkaitan antar konsep dan mengaplikasikan konsep atau algoritma secara luwes, akurat, efisien, dan cepat dalam pemecahan masalah.

Peraturan Dirjen Dikdasmen Depdiknas Nomor 506/C/Kep/PP/2004 tanggal 11 November 2004 tentang rapor (Wardhani, 2008) diuraikan bahwa indikator siswa memahami konsep matematika adalah mampu:

1. Menyatakan ulang sebuah konsep,

2. Mengklasifikasi objek menurut sifat-sifat tertentu sesuai dengan konsepnya,

3. Memberi contoh dan bukan contoh dari suatu konsep,

4. Menyajikan konsep dalam berbagai bentuk representasi matematis,

5. Mengembangkan syarat perlu atau syarat cukup dari suatu konsep,

6. Menggunakan dan memanfaatkan serta memilih prosedur atau operasi tertentu,

7. Mengaplikasikan konsep atau algoritma pada pemecahan masalah.

Dengan demikian, pada penelitian ini subjek dikatakan memahami konsep matematika ketika mampu memenuhi ketujuh indikator pemahaman konsep.

\section{E-learning}

Menurut Stockley (2014) e-learning adalah proses penyampaian program pembelajaran, pelatihan atau pendidikan secara elektronik. Penggunaan e-learning dapat diakses dimana saja, baik pada perangkat komputer atau smartphone. Cahyadi (2016) mengungkapkan e-learning yang menggunakan konsep student centered mampu membuat peserta didik memperoleh kesempatan dan fasilitas untuk membangun sendiri pengetahuannya yang mendalam dan pada akhirnya meningkatkan mutu kualitas peserta didik.

Berikut ini merupakan karakteristik e-learning yang dikemukakan Riyana dalam Choirudin (2015):

1. Daya tangkap siswa terhadap materi pembelajaran tidak tergantung kepada instruktur/guru, karena siswa mengkonstruk sendiri ilmu pengetahuannya melalui bahanbahan ajar yang disampaikan melalui interface situs web;

2. Sumber ilmu pengetahuan tersebar di mana- mana serta dapat diakses dengan mudah oleh setiap orang. Hal ini dikarenakan sifat media internet yang mengglobal dan bisa diakses oleh siapapun yang terkoneksi ke dalamnya;

3. Pengajar/ lembaga pendidikan berfungsi sebagai mediator/pembimbing;

4. Diperlukan sebuah restukturisasi terhadap kebijakan sistem pendidikan, kurikulum, dan manajemen yang dapat mendukung pemanfaatan teknologi informasi dan komunikasi untuk pendidikan secara optimal.

\section{Quipper Video}

Salah satu produk e-learning yang telah mengikuti perkembangan teknologi informasi dan komunikasi adalah Quipper Video. Quipper Video berisikan pembelajaran berbasis video secara online, ringkasan materi serta latihan soal bagi peserta didik. Quipper video didesain khusus untuk pendidikan menengah dengan isi materi ajar sesuai dengan kurikulum yang ada di 
Indonesia yaitu Kurikulum Tingkat Satuan Pendidikan (KTSP) dan Kurikulum 2013 (K-13). Dijelaskan pula pada penelitian yang dilakukan oleh Lingga (2016) bahwa jika siswa menggunakan Quipper cenderung memiliki hasil belajar yang lebih baik dengan intensitas penggunaan Quipper yang sangat baik pula karena tertarik dengan adanya media tersebut. Krisna dan Marga (2017) menyatakan bahwa penggunaan video untuk pembelajaran cukup menunjang pembelajaran karena pada masa sekarang siswa lebih tertarik dengan visual daripada dengan metode konvensional atau ceramah. Sehingga dengan penggunaan Quipper Video peserta didik dapat lebih termotivasi dalam belajar di berbagai tempat dan situasi.

\section{METODE PENELITIAN}

Jenis penelitian ini adalah penelitian deskriptif kualitatif. Subjek terdiri dari 3 siswa yang dipilih secara acak dengan kriteria 1) siswa dengan intensitas penggunaan quipper video tinggi; 2) siswa dengan intensitas penggunaan quipper video sedang; dan 3) siswa dengan intensitas penggunaan quipper video rendah. Instrumen yang digunakan telah divalidasi oleh 2 orang validator. Teknik pengumpulan data yang digunakan meliputi pemberian angket intensitas penggunaan quipper video untuk pengambilan subjek penelitian yang kemudian diberikan tes pemahaman konsep matematika materi perpangkatan. Setelah menyelesaikan soal pada tes tersebut dilakukan wawancara. Untuk memeriksa keabsahan data dalam penelitian ini digunakan teknik triangulasi waktu dengan teknik analisis data menurut Miles, Huberman \& Saldana (2014) meliputi kondensasi data, penyajian data, lalu penarikan kesimpulan.

\section{HASIL DAN PEMBAHASAN}

Gambaran Kuantitatif Intensitas Penggunaan Quipper Video

Intensitas penggunaan quipper video yang dimaksud adalah frekuensi dengan waktu penggunaan quipper video oleh siswa selama belajar matematika. Siswa yang dimaksud pada penelitian ini adalah siswa SMP kelas IX yang berjumlah 34 orang.

TABEL 1. Deskripsi Kuantiatif Intensitas Penggunaan Quipper Video Siswa

\begin{tabular}{llc}
\hline \multicolumn{2}{c}{ Deskripsi } & Persentase \\
\hline Pemberian Intensitas & Penggunaan & $55,8 \%$ \\
Quipper Video & \\
$\begin{array}{l}\text { Merasakan Manfaat } \\
\text { Quipper Video }\end{array}$ & Penggunaan & \\
Mengalami keefektivan $\quad$ Quipper \\
Video
\end{tabular}

Tabel 1 menunjukkan bahwa terdapat 55,8 \% siswa memberikan intensitas penggunaan Quipper Video sebagai alternatif lain pemilihan sumber belajar. Intensitas penggunaan Quipper Video tersebut adalah menggunakan Quipper Video untuk belajar matematika saat mempunyai waktu luang untuk belajar matematika, dalam keadaan memiliki kegiatan lain siswa menyempatkan untuk mengakses Quipper Video untuk belajar matematika, menjadikan Quipper Video sebagai sumber belajar ketika ketika menyelesaikan tugas-tugas matematika, siswa menggunakan Quipper Video 2 kali sepekan, tidak setuju jika dinyatakan bahwa Quipper Video hanya digunakan ketika mengalami kesulitan belajar matematika.

Terdapat 64,7 \% siswa merasakan manfaat dari penggunaan Quipper Video. Manfaat dari penggunaan Quipper Video yang siswa rasakan berupa informasi dari materi matematika yang didapatkan dari Quipper Video sudah cukup jelas, ketika belajar matematika di Quipper Video lebih disukai daripada belajar di buku dan LKS, mengerjakan kuis yang tersedia dalam Quipper Video untuk menguji pengetahuan matematika yang siswa pahami, ketika kurang memahami 
yang dijelaskan oleh guru siswa menggunakan Quipper Video sebagai sumber belajar matematika pengganti.

Terdapat 58,8 \% siswa mengalami keefektivan Quipper Video dalam balajar matematika. Keefektivan Quipper Video yang dimaksud adalah Quipper Video dapat digunakan dimanapun siswa berada, tidak ada kendala ketika belajar matematika menggunakan Quipper Video, dengan belajar di Quipper Video siswa dapat terbantu dalam memahami materi pelajaran matematika, saat mengerjakan soal dari guru menjadi lebih mudah juga sesuai dengan materi yang telah dipelajari karena menggunakan Quipper Video, ketika belajar matematika di Quipper Video siswa menjadi bersemangat dan tidak bosan, tidak ada kendala ketika menggunakan Quipper Video sehingga dapat menunjang pengetahuan pada pelajaran matematika, tidak hanya membuka Quipper Video untuk belajar matematika, ketika menggunakan Quipper Video materi matematika dapat dimengerti, dapat memperoleh hasil belajar dengan maksimal.

\section{Gambaran Kuantitatif dan Kualitatif Pemahaman Konsep Perpangkatan Subjek Penelitian}

Setelah subjek belajar tentang perpangkatan melalui Quipper Video, subjek diberi tes pemahaman konsep. Untuk menguji apakah subjek memiliki pemahaman konsep yang baik setelah belajar melalui Quipper Video. Berikut gambaran kuantitaif pemahaman konsep subjek tes pertama.

TABEL 2. Gambaran Kuantiataif Pemahaman Konsep Subjek

\begin{tabular}{|c|c|c|c|c|c|c|}
\hline \multirow{2}{*}{$\begin{array}{l}\text { Indikator Pemahaman } \\
\text { Konsep }\end{array}$} & \multicolumn{6}{|c|}{ Skor Pencapaian } \\
\hline & T1 & T2 & S1 & S2 & R1 & $\mathbf{R 2}$ \\
\hline $\begin{array}{l}\text { 1. Menyatakan ulang } \\
\text { sebuah konsep. }\end{array}$ & 5 & 5 & 10 & 10 & 10 & 5 \\
\hline $\begin{array}{l}\text { 2. Mengklasifikasi objek } \\
\text { menurut sifat-sifat } \\
\text { tertentu sesuai dengan } \\
\text { konsepnya. }\end{array}$ & 7 & 7 & 15 & 15 & 7 & 15 \\
\hline $\begin{array}{l}\text { 3. Menggunakan dan } \\
\text { memanfaatkan serta } \\
\text { memilih prosedur atau } \\
\text { operasi tertentu. }\end{array}$ & 15 & 15 & 15 & 7 & 15 & 15 \\
\hline $\begin{array}{l}\text { 4. Mengaplikasikan } \\
\text { konsep dan algoritma } \\
\text { pada pemecahan } \\
\text { masalah. }\end{array}$ & 20 & 20 & 20 & 20 & 0 & 20 \\
\hline $\begin{array}{l}\text { 5. Memberi contoh dan } \\
\text { bukan contoh. }\end{array}$ & 5 & 10 & 10 & 10 & 5 & 0 \\
\hline $\begin{array}{l}\text { 6. Menyajikan konsep } \\
\text { dalam berbagai bentuk } \\
\text { representasi matematis. }\end{array}$ & 10 & 10 & 10 & 10 & 10 & 10 \\
\hline $\begin{array}{l}\text { 7. Mengembangkan syarat } \\
\text { perlu dan syarat cukup } \\
\text { dari suatu konsep. }\end{array}$ & 20 & 20 & 20 & 20 & 10 & 15 \\
\hline
\end{tabular}

Keterangan:

T1 : Pengguna Quipper Video dengan intensitas tinggi tes pertama

T2 : Pengguna Quipper Video dengan intensitas tinggi tes kedua

S1 : Pengguna Quipper Video dengan intensitas sedang tes pertama

S2 : Pengguna Quipper Video dengan intensitas sedang tes kedua

R1 : Pengguna Quipper Video dengan intensitas rendah tes pertama

R2 : Pengguna Quipper Video dengan intensitas rendah tes kedua 
Berdasarkan Tabel 2 diperoleh bahwa intensitas Sedang memiliki jumlah skor pencapaian yang paling tinggi diikuti Subjek Intensitas Tinggi dan Subjek Intensitas Rendah berturut-turut. Begitu pula hasil tes kedua, Subjek Intensitas Sedang tetap menunjukkan jumlah skor pencapaian yang lebih tinggi lalu diikuti dengan Subjek Intensitas Tinggi, dan Subjek Intensitas Rendah.

\section{Subjek dengan Intensitas Penggunaan Quipper Video Tinggi}

Indikator 1

Pada indikator menyatakan ulang konsep, subjek menyatakan "bilangan berpangkat adalah bilangan yang berulang". Subjek kurang lengkap dalam menyatakan definisi bilangan berpangkat yang seharusnya adalah perkalian berulang dengan bilangan yang sama. Namun saat wawancara subjek mampu menjelaskan bilangan berulang yang dimaksudkan "bilangan pokok yang berulang misalkan $2^{2}$ itu 2 kali 2 sama dengan 4". Sehingga subjek dinyatakan mampu menyatakan ulang sebuah konsep bilangan berpangkat.

Indikator 2

$$
\begin{aligned}
& \text { 2. a. } 9 a \times a^{2} \times c \times 3 c^{2} \\
& 9 a^{3} \times 3 c^{3} \\
& \text { b. } \frac{4 p \times 28 q^{8}}{4^{2} p q^{4}}=\frac{4 \times 28 \times p \times q^{8}}{4 \times 4 \times p \times q^{4}} \\
& =7 a^{8-4}=7 a^{4}
\end{aligned}
$$

GAMBAR 1. Paparan hasil tes subjek intensitas tinggi nomor 2

Untuk indikator menggunakan dan memanfaatkan serta memilih prosedur atau operasi tertentu, Pada Gambar 1 subjek mampu menyederhanakan bentuk bilangan berpangkat yang diberikan dengan memanfaatkan sifat-sifat bilangan berpangkat dan memilih operasi yang tepat subjek gunakan. Sehingga subjek dinyatakan mampu menggunakan dan memanfaatkan serta memilih prosedur atau operasi tertentu pada suatu masalah.

Indikator 3

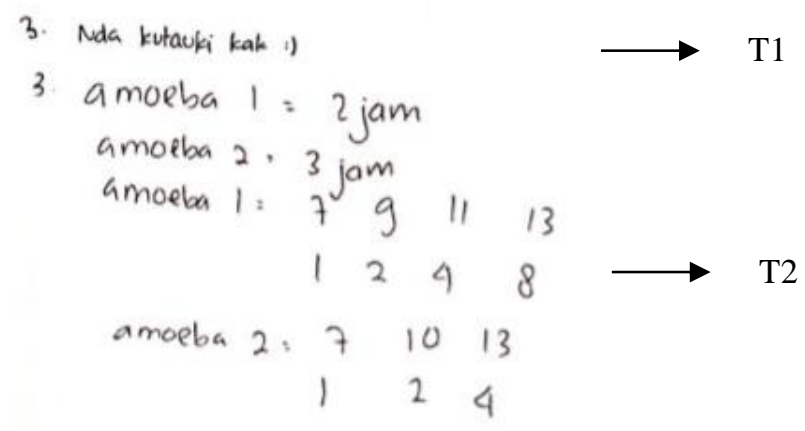

GAMBAR 2. Paparan hasil tes subjek intensitas tinggi nomor 3

Untuk indikator mengaplikasikan konsep dan algoritma pada pemecahan masalah, terlihat pada Gambar 2 bahwa awalnya subjek tidak mengetahui penyelesaian yang tepat (T1). Kemudian subjek dapat menuliskan informasi yang diperoleh dari soal, banyaknya amoeba dan menguraikannya setiap jam tanpa menuliskan jumlah amoeba secara keseluruhan (T2). Namun saat dilakukan wawancara, subjek mengakui bahwa dia mencontek jawaban temannya. Dengan 
demikian subjek tidak mampu mengaplikasikan konsep atau algoritma pada masalah yang diberikan.

Indikator 4

Pada indikator mengklasifikasi objek menurut sifat-sifat tertentu sesuai dengan konsepnya, subjek mampu menjelaskan sifat-sifat bilangan berpangkat positif dengan lengkap dan tepat beserta contohnya. Sifat-sifat bilangan berpangkat bulat positif meliputi $a^{m} \times b^{n}=$ $a^{m+n}, a^{m}: a^{n}=a^{m-n},(a \times b)^{m}=a^{m} \times b^{m},\left(a^{m}\right)^{n}=a^{m \times n}$, dan $\left(\frac{a}{b}\right)^{m}=\frac{a^{m}}{b^{m}}$ dengan $b \neq 0$. Sehingga subjek dikatakan mampu mengklasifikasikan objek menurut sifat-sifat tertentu sesuai dengan konsepnya.

Indikator 5

Pada indikator memberi contoh dan bukan contoh, subjek tidak menuliskan contoh dari bilangan berpangkat bulat negatif, melainkan pendefinisian bilangan berpangkat bulat negatif secara matematis yang dapat dilihat pada Gambar 3 .

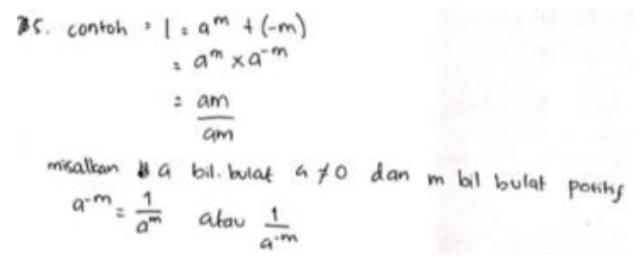

GAMBAR 3. Paparan hasil tes subjek intensitas tinggi nomor 5

Namun ketika dilakukan wawancara subjek mampu memberikan contoh dan bukan contoh dari bilangan berpangkat bulat negatif dengan tepat. Subjek berkata "kayak $\mathrm{hmm}$ ini $6^{-4}$ pangkat negatif. Kalau pangkat positif itu yang $6^{4}$ ". Sehingga subjek mampu memberikan contoh dan bukan contoh dari suatu konsep.

Indikator 6

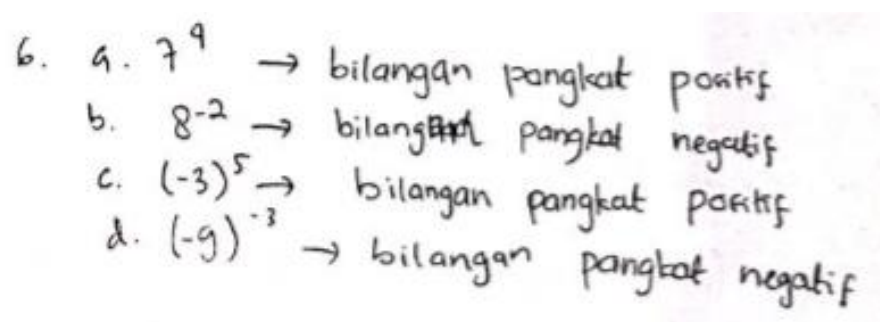

GAMBAR 4. Paparan hasil tes subjek intensitas tinggi nomor 6

Pada indikator menyajikan konsep dalam berbagai bentuk representasi matematis, terlihat pada Gambar 4 subjek mampu membedakan bilangan berpangkat positif dan bilangan berpangkat negatif. Subjek mampu mengelompokkan masalah yang diberikan pada bilangan berpangkat negatif dan pada bilangan berpangkat positif. Sehingga subjek mampu menyajikan konsep dalam berbagai bentuk representasi matematis.

\section{Indikator 7}

Pada indikator mengambangkan syarat perlu dan syarat cukup dari suatu konsep, subjek mengungkapkan bahwa prinsip yang ada pada $6^{5}$ tidak sama dengan prinsip pada $6^{-3}$ karena memiliki tanda negatif sehingga berbeda dalam penjabaran. Subjek juga mampu menjelaskan dengan tepat bahwa hasil dari $(-2) \times(-2) \times(-2)$ adalah $(-2)^{3}$ karena setiap angka memiliki pangkat positif yaitu 1 , untuk $2^{-3}$ subjek mampu menjelaskan penyelesaiannya menggunakan prinsip perpangkatan bilangan negatif yaitu $2^{-3}=\frac{1}{2^{3}}$. Dengan demikian subjek mampu memahami syarat perlu dan syarat cukup dari suatu konsep. 
Pemahaman konsep subjek intensitas tinggi terkait perpangkatan berdasar pada analisis data dan pembahasan bahwa subjek intensitas tinggi masih memiliki kekeliruan dalam menyelesaikan soal. Sehingga melihat dari indikator pemahaman konsep Peraturan Dirjen Dikdasmen Depdiknas Nomor 506/C/Kep/PP/2004 tanggal 11 November 2004 tentang rapor (Warhdani, 2008), subjek dengan intensitas penggunaan quipper video tinggi tidak mampu mengaplikasikan konsep atau algoritma pada pemecahan masalah. Dengan demikian, subjek intensitas tinggi hanya memiliki pemahaman konsep yang cukup baik.

\section{Subjek dengan Intensitas Penggunaan Quipper Video Sedang}

Indikator 1

Pada indikator menyatakan ulang konsep, subjek mampu menjelaskan yang dimaksud dengan bilangan berpangkat dengan jelas dan tepat. Subjek menyatakan bahwa bilangan berpangkat adalah perkalian berulang dengan bilangan yang sama, banyaknya tergantung jumlah pangkatnya. Sehinggu subjek dinyatakan mampu menyatakan ulang konsep.

Indikator 2

Pada indikator menggunakan dan memanfaatkan serta memilih prosedur atau operasi tertentu, subjek mampu menyederhanakan bentuk-bentuk perpangkatan yang diberikan dengan memilih operasi yang dapat subjek gunakan.

\section{Transkrip 1}

P-03 dari soal nomor2 kan disuruh sederhanakan bentukbentuknya, coba jelaskan sifat-sifat yang kamu pakai saat menyederhanakan soal nomor 2

SIS2-W103 hm? yang B itu kan pembagian pangkatnya dikurang

P-04 kalau perkalian?

SIS2-W104 pangkatnya ditambah

Saat wawancara terlihat pada transkrip 1 subjek menjelaskan sifat-sifat yang ia gunakan dalam menyederhanakan soal bahwa untuk operasi pembagian, pangkat yang dimiliki basis yang sama itu dikurang (SIS2-W103) dan untuk operasi perkalian, pangkat yang dimiliki basis yang sama itu dijumlahkan (SIS2-W104). Sehingga subjek mampu menggunakan dan memanfaatkan serta memilih prosedur atau operasi tertentu.

\section{Indikator 3}

Pada indikator mengaplikasikan konsep dan algoritma pada pemecahan masalah, subjek mampu menuliskan informasi yang dia dapatkan dari masalah yang diberikan. Subjek menuliskan dengan singkat total amoeba 1 pada akhir jam yang ditentukan, begitu juga total amoeba 2 dan menjumlahkan amoeba 1 dan amoeba 2 sehingga menghasilkan 12 amoeba yang dapat dilihat pada Gambar 5.

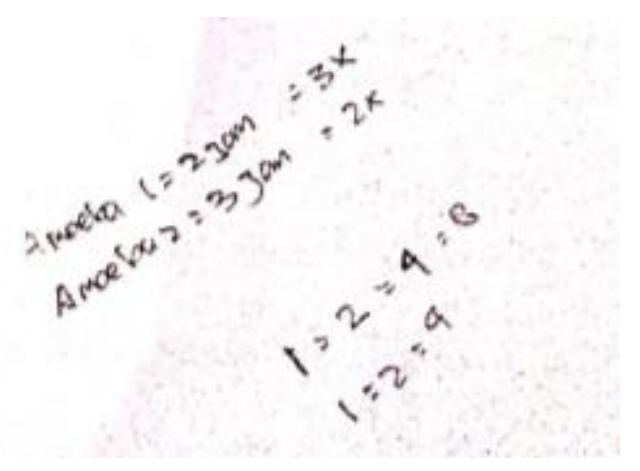

GAMBAR 5. Paparan hasil tes subjek intensitas sedang nomor 2 
Subjek mampu menjelaskan dengan rinci mengenai jawaban yang ia tuliskan dan menjelaskan proses penjumlahan dari pembelahan amoeba yang terjadi pada amoeba 1 per 2 jam dan amoeba 2 per 3 jam hingga total amoeba secara keseluruhan yaitu 12 amoeba (SIS3-W214). Subjek juga menjelaskan bahwa operasi yang ia gunakan pada penyelesaian masalah yang diberikan yaitu perpangkatan jumlah awal amoeba membelah diri (SIS3-W211 dan SIS3-W212) yang dapat dilihat pada Transkrip 2.

\section{Transkrip 2}

SIS3-W211 Kan jam 7.00 ke jam 13.00 itu 6 jam toh kak. Amoeba 1 itu setiap 2 jam. Amoeba itu membelah dari 1 itu jadi 2, terus 2

P-12 jadi amoeba itu setiap membelah kalau dimatematikakan operasi apa?

SIS3-W212 dipangkatkan. Pangkat 2 sетиa

P-13 kenapa?

SIS3-W213 karena amoeba itu satu kali membelah jadi 2

P-14 jadi berapa amoeba yang dihasilkan?

SIS3-W214 hmm 12 amoeba

Dengan demikian, subjek intensitas sedang dinyatakan mampu mengampilkasikan konsep atau algoritma pada pemecahan masalah.

Indikator 4

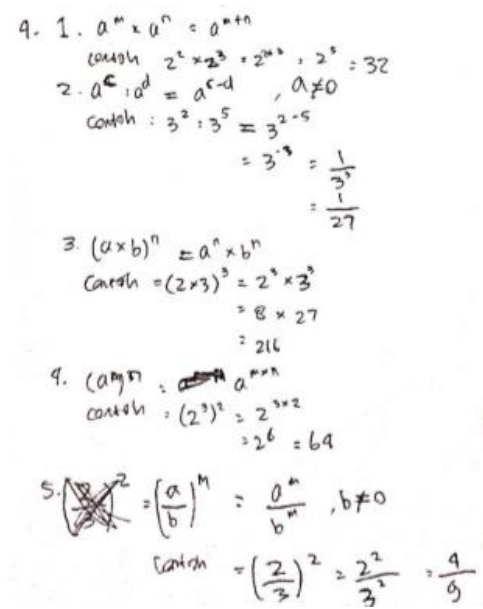

GAMBAR 4. Paparan hasil tes subjek intensitas sedang nomor 4

Untuk indikator mengklasifikasi objek menurut sifat-sifat tertentu sesuai dengan konsepnya, dapat dilihat pada Gambar 4 subjek mampu menuliskan sifat-sifat bilangan berpangkat positif dengan lengkap dan tepat beserta contoh yang subjek selesaikan sendiri. Sehingga subjek mampu mengklasifikasikan objek menurut sifat-sifat tertentu sesuai dengan konsepnya.

Indikator 5

Pada indikator memberi contoh dan bukan contoh, subjek mampu menuliskan contoh-contoh dari bilangan berpangkat bulat negatif serta yang bukan contoh dari bilangan berpangkat bulat negatif. Subjek mengungkapkan bahwa contoh bilangan berpangkat bulat negatif yaitu bilangan yang memiliki pangkat negatif seperti $8^{-2},(-2)^{-5}, 9^{-3}$ dan seterusnya. Begitu pula sebaliknya untuk yang bukan bilangan pangkat negatif yaitu bilangan yang memiliki pangkat positif seperti $8^{5},(-2)^{10}, 9^{5}$ dan seterusnya. Sehingga subjek mampu memberikan contoh dan bukan contoh dari suatu konsep.

Indikator 6 
Pada indikator menyajikan konsep dalam berbagai bentuk representasi matematis, subjek mampu menentukan bilangan berpangkat positif dan bilangan berpangkat negatif dengan tepat. Dapat dilihat pada Gambar 5. Sehingga subjek dinyatakan mampu menyajikan konsep dalam berbagai bentuk representasi matematis.

$$
\begin{aligned}
& \text { c. a. } 7^{4}=\text { Berparguat positic } \\
& \text { b. } \mathbb{S}^{-2}=\text { Berparghat Nogatiz } \\
& \text { c. }(-3)^{5}=\text { Eerpangluat patffe } \\
& \text { d. }(-9)^{-3}=\text { Exrperghat Negatif }
\end{aligned}
$$

GAMBAR 5. Paparan hasil tes subjek intensitas sedang nomor 6

Indikator 7

Pada indikator mengembangkan syarat perlu atau syarat cukup dari suatu konsep, subjek mampu menyatakan bahwa prinsip yang digunakan pada $6^{5}$ tidak berlaku pada $6^{-3}$ karena $6^{-3}$ memiliki pangkat negatif sehingga berbeda penyelesaian. Subjek juga mampu menyatakan dengan tepat bahwa hasil dari $(-2) \times(-2) \times(-2)$ tidak sama dengan $2^{-3}$ karena jika berpangkat negatif maka penyelesaian yang diubah ke bentuk positif menjadi bilangan pecahan. Sedangkan penyelesaian dari soal tersebut berpangkat positif sehingga jawaban yang subjek tuliskan dengan tepat adalah $(-2)^{3}$. Subjek mengungkapkan bahwa penjabaran bilangan berpangkat negatif berbeda dengan bilangan berpangkat positif. Sehingga subjek mampu mengembangkan syarat perlu dan syarat cukup dari suatu konsep.

Jika diamati dari indikator yang dipahami, subjek intensitas sedang dapat memahami konsep dengan baik karena sebagaimana yang telah dijelaskan pada Kajian Pustaka bahwa siswa dikatakan dapat memahami konsep dengan baik jika terpenuhi 7 indikator Peraturan Dirjen Dikdasmen Depdiknas Nomor 506/C/Kep/PP/2004 tanggal 11 November 2004 tentang rapor (Warhdani, 2008).

\section{Subjek dengan Intensitas Penggunaan Quipper Video Rendah}

Indikator 1

Pada indikator menyatakan ulang sebuah konsep, subjek menyatakan ulang yang dimaksud dengan perpangkatan dengan bahasanya sendiri. Subjek menyatakan bahwa bilangan berpangkat merupakan bilangan berulang dan mempunyai bilangan yang sama dengan contoh $4^{2}=4 \times 4$. Meski begitu, subjek tidak menjelaskan bahwa bilangan berulang yang dimaksudkan haruslah perkalian berulang dengan bilangan yang sama. Sehingga subjek belum mampu menyatakan ulang konsep bilangan berpangkat dengan benar.

Indikator 2

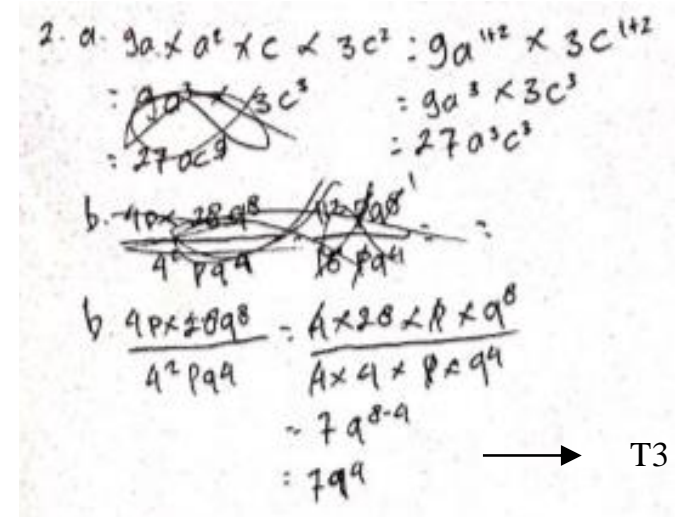

GAMBAR 6. Paparan hasil tes subjek intensitas rendah nomor 2 
Pada indikator menggunakan dan memanfaatkan serta memilih prosedur atau operasi tertentu, terlihat pada Gambar 6 subjek mampu menyederhanakan bentuk-bentuk perpangkatan yang diberikan dengan memilih operasi yang dapat subjek gunakan dengan tepat. Subjek juga mampu menjelaskan operasi serta sifat-sifat bilangan berpangkat yang digunakan saat mengerjakan soal, bahwa untuk operasi pembagian maka pangkatnya di kurangi (T3). Sehingga subjek mampu menggunakan dan memanfaatkan serta memilih prosedur atau operasi tertentu pada masalah yang diberikan.

Indikator 3

\author{
Transkrip 3 \\ SIR3-W207 karena pertama 1 amoeba dikalikan 2 jadi 2, terus 2 kali 2 lagi \\ jadi 4 , teruus yang ke tigakalinya 4 kali 2 jadi 8 \\ P-08 kenapa bisa dikali 2? \\ SIR3-W208 karena dia membelah diri jadi 2 ki, jadi pas 2 amoeba membelah \\ diri lagi jadi 2 jadi 4 amoeba \\ P-09 jadi berapa total keseluruhan amoeba? \\ SIR3-W209 amoeba 1 dengan amoeba 2 totalnya hmm ku lupa berapa \\ P-10 kenapa dilupa? Coba jumlahkan saja amoeba 1 dengan amoeba 2, \\ berapa totalnya? \\ SIR3-W210 hmm 12
}

Subjek mampu menuliskan informasi yang ia dapatkan dari masalah yang diberikan secara rinci pada setiap pergantian jam yang ditentukan dengan tepat. Pada transkrip 3 subjek menjelaskan bahwa setiap amoeba yang membelah diri dikalikan dengan 2 dari jumlah amoeba sebelumnya karena adanya pernyatan membelah diri sehingga satu amoeba menjadi dua amoeba (SIR3W208). Walaupun subjek tidak menuliskan jumlah keseluruhan dari amoeba, setelah diberikan pertanyaan lebih jelas lagi subjek mampu menjawab dengan benar total keseluruhan amoeba yang subjek dapatkan yaitu 12 amoeba (SIR3-W210). Sehingga untuk indikator mengaplikasikan konsep dan algoritma dalam pemecahan masalah, subjek mampu mengaplikasikan konsep atau algoritma pada pemecahan masalah.

Indikator 4

Pada indikator mengklasifikasi objek menurut sifat-sifat terntentu sesuai dengan konsepnya, subjek mampu menuliskan serta menjelaskan sifat-sifat dari bilangan berpangkat positif dengan lengkap dan tepat. Meliputi $a^{m} \times b^{n}=a^{m+n}, a^{m}: a^{n}=a^{m-n},(a \times b)^{m}=a^{m} \times$ $b^{m},\left(a^{m}\right)^{n}=a^{m \times n}$, dan $\left(\frac{a}{b}\right)^{m}=\frac{a^{m}}{b^{m}}$ dengan $b \neq 0$. Subjek juga menuliskan contoh dari masing-masing sifat bilangan berpangkat yang ia tuliskan. Sehingga subjek mampu mengklasifikasikan objek menurut sifat-sifat tertentu sesuai dengan konsepnya.

Indikator 5

Pada indikator memberi contoh dan bukan contoh, subjek menjelaskan definisi dari bilangan berpangkat negatif yang ia pahami adalah pangkat yang memiliki tanda negatif. Ketika dimintai contoh mengenai bilangan berpangkat bulat negatif, subjek kesulitan dalam memberikan contoh. Dapat dilihat pada transkrip 4 sebagai berikut;

\title{
Transkrip 4
}

SIR5-W212

bilangan bulat pangkat negatif hmm misalnya a pangkat 2 mines 2

sama dengan a pangkat 2 per a pangkat 2

$P-13 \quad$ bagaimana yang dimaksud bilangan pangkat negatif kah?

SIR5-W213 bilangan yang pangkatnya itu mines atau kurang

$P-14 \quad$ jadi apa contohnya?

SIR5-W214 itu a $a^{2-2}$ di situ pangkatnya negatif atau kurang

$P-15 \quad k a n$ kalau $2-2$ jadinya $a^{0}$ nol itu positif atau negatif?

SIR5-W215 hmm negatif 


$\begin{array}{ll}\text { P-16 } & \text { terus bilangan pangkat positif? } \\ \text { SIR5-W216 } & \begin{array}{l}\text { bilangan pangkat positif itu yang tambah. Misalkan } a^{3+3}=\frac{a^{3}}{a^{3}} \\ \text { positif } \\ \text { jadi kalau misalkan } a^{2-1} \text {. Itu bilangan pangkat positif atau } \\ \text { negatif? }\end{array} \\ \begin{array}{l}a^{2-1} ? \text { hmm negatif karena pangkatnya dikurangkan } \\ \text { SIR5-W217 }\end{array} & \begin{array}{l}\text { tapi hasil dari pangkatnya itu positif atau negatif? } \\ \text { hasilnya? Positif. Tapi kan di situ ada pangkatnya negatif }\end{array} \\ \text { SIR5-W218 } & \begin{array}{l}\text { tapi kan hasilnya } a^{1} \\ \text { iya tapi sebelumnya itu pangkat negatif ki karena ada tanda }\end{array} \\ \text { SIR5-W219 } & \begin{array}{l}\text { minesnya } \\ \text { misalkan ada } a^{-2}, \text { itu pangkat negatif atau positif? } \\ \text { negatif. Tapi yang ku dapat itu kak kalau misalnya ada } \\ \text { pangkatnya negatif itu termasuk di pangkat negatif biar hasilnya } \\ \text { positif }\end{array}\end{array}$

Terlihat pada kutipan SIR5-W220, subjek keliru dalam mengartikan konsep bilangan berpangkat negatif. Walaupun subjek diberi pertanyaan lanjutan seperti pada P-17, subjek tetap yakin bahwa pangkat yang dimiliki contoh itu pangkat negatif (SIR5-W218). Sehingga subjek belum mampu membedakan contoh dan bukan contoh dari bilangan berpangkat negatif.

Indikator 6
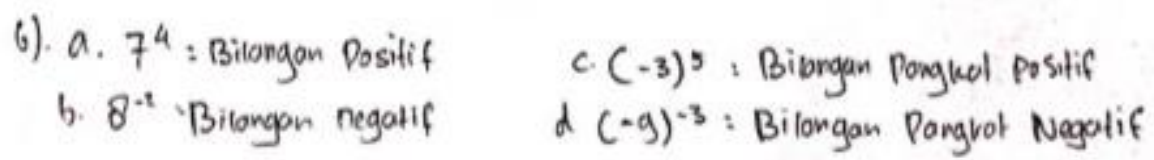

GAMBAR 7. Paparan hasil tes subjek intensitas rendah nomor 6

Pada indikator menyajikan konsep dalam berbagai bentuk representasi matematis, dari Gambar 7 terlihat bahwa subjek mampu menentukan serta merepresentasikan bilangan berpangkat positif dan bilangan berpangkat negatif dengan tepat. Sehingga subjek mampu menyajikan konsep dalam berbagai bentuk representasi matematis.

Indikator 7

Pada indikator mengambangkan syarat perlu atau syarat cukup dari suatu konsep, subjek mampu menjelaskan bahwa $(-2) \times(-2) \times(-2)$ sama dengan $(-2)^{3}$. Namun subjek keliru dalam menyatakan bahwa prinsip yang digunakan pada $6^{5}$ juga berlaku pada $6^{-3}$ dikarenakan hasil yang juga sama-sama banyak tanpa menyebutkan secara pasti hasil dari perpangkatan tersebut. Subjek masih belum mampu menjelaskan prinsip penjabaran pada bilangan yang berpangkat positif maupun bilangan berpangkat negatif. Sehingga, subjek belum mampu mengembangkan syarat perlu atau syarat cukup dari suatu konsep.

Pemahaman konsep pada subjek intensitas rendah dalam menyelesaiakan masalah terkait perpangkatan berdasarkan pada analisis data dan pembahasan bahwa subjek intensitas rendah masih memiliki kekeliruan dalam memahami konsep. Baik itu definisi perpangkatan, memberikan contoh dan bukan contoh dari suatu masalah, serta mengembangkan syarat perlu atau syarat cukup dari suatu konsep. Dengan demikian, berdasarkan indikator siswa dikatakan memahami konsep apalabila memenuhi 7 indikator Peraturan Dirjen Dikdasmen Depdiknas Nomor 506/C/Kep/PP/2004 tanggal 11 November 2004 tentang rapor (Warhdani, 2008) subjek dengan intensitas penggunaan quipper video rendah memiliki pemahaman konsep yang kurang baik. 


\section{Keterkaitan Antar Intensitas Penggunaan Quipper Video dengan Pemahaman Konsep Perpangkatan}

Berdasarkan paparan data dari tes dan wawancara yang telah dilakukan bahwa tidak adanya hubungan antara intensitas penggunaan quipper video dengan pemahaman konsep yang dimiliki oleh siswa. Penelitian yang juga menerapkan e-learning dalam pembelajaran mengungkapkan bahwa penerapan media e-learning quipper school tidak efektif jika ditinjau dari hasil belajar, aktivitas dan respon siswa karena kurangnya motivasi dan kemampuan matematika yang dinilai kurang (Cahyadi 2016). Terlihat dalam gambaran kuantitatif dan kualitatif dari subjek, subjek yang intensitas penggunaan quipper video tinggi tidak memenuhi semua indikator dari pemahaman konsep Peraturan Dirjen Dikdasmen Depdiknas Nomor 506/C/Kep/PP/2004 tanggal 11 November 2004 sehingga subjek dengan intensitas tinggi menunjukkan skor hasil pencapaian dari tes pemahaman konsep pertama yaitu 82 dan tes yang kedua yaitu 87 . Dengan demikian, subjek intensitas tinggi belum memahami konsep perpangkatan dengan baik meskipun intensitas penggunaan quipper video-nya tinggi. Sementara subjek dengan intensitas penggunaan quipper video rendah juga tidak memenuhi semua indikator pemahaman konsep, dengan skor pencapaian pada tes pemahaman konsep yang pertama yaitu 51 dan tes yang kedua yaitu 80. Sehingga subjek intensitas rendah dikatakan tidak memahami konsep perpangkatan dengan baik. Sedangkan pada penelitian Saputra dan Mujib (2018) tentang efektivitas model flipped classroom menggunakan video pembelajaran matematika terhadap pemahaman konsep mengungkapkan bahwa pemahaman konsep matematis siswa yang diterapkan flipped classroom menggunakan video pembelajaran lebih baik dari kemampuan pemahaman konsep yang diterapkan dengan metode ceramah. Hal ini juga ditemui pada subjek dengan intensitas penggunaan quipper video sedang bahkan dapat memenuhi ketujuh indikator pemahaman konsep yang ditentukan sebelumnya dengan skor pencapaian pada tes pemahaman konsep yang pertama yaitu 100 dan tes yang kedua yaitu 91. Pada tes yang kedua subjek intensitas sedang sempat keliru dalam menjawab soal, namun pada saat wawancara subjek mampu menjelaskan kesalahannya. Sehingga subjek dengan intensitas sedang dapat memahamai konsep perpangkatan dengan baik.

\section{KESIMPULAN}

Hasil penelitian diperoleh bahwa pamahaman konsep matematika siswa ditinjau dari intensitas penggunaan quipper video yaitu pada subjek dengan intensitas sedang memiliki pemahaman konsep yang lebih baik dari subjek dengan intensitas penggunaan quipper video tinggi dan rendah.

(1) Subjek dengan intensitas penggunaan quipper video tinggi kurang memahami konsep pada indikator mengaplikasikan konsep atau algoritma pada pemecahan masalah. (2) Subjek dengan intensitas penggunaan quipper video sedang mampu menyatakan ulang konsep, mengklasifikasi objek menurut sifat-sifat tertentu sesuai dengan konsepnya, menggunakan dan memanfaatkan serta memilih prosedur atau operasi tertentu, mengaplikasikan konsep atau algoritma pada pemecahan masalah, memberikan contoh dan bukan contoh, menyajikan konsep dalam berbagai representasi matematis, dan mengembangkan syarat perlu atau syarat cukup dari suatu konsep. (3) Subjek dengan intensitas penggunaan quipper video rendah kurang memahami konsep pada indikator menyatakan ulang suatu konsep, memberikan contoh dan bukan contoh dari suatu konsep, dan mengembangkan syarat perlu atau syarat cukup dari suatu konsep.

Hasil penelitian ini menunjukkan bahwa pemahaman konsep matematika siswa dalam materi perpangkatan masih kurang. Bagi peneliti lain yang akan melakukan penelitian serupa, dapat pula memberikan gambaran pemahaman konsep siswa dengan memperhatikan gender atau penggunaan e-learning berbasis video yang lain dengan materi berbeda. 


\section{DAFTAR PUSTAKA}

Cahyadi, R. (2016). Efektivitas Penerapan E-Learning Quipper School Dalam Pembelajaran Matematika Siswa Kelas X SMA Negeri 6 Makassar (Skripsi). Universitas Negeri Makassar, Makassar.

Choirudin. (2015). Efektivitas Pembelajaran Matematika dengan E-learning Berbasis Schoology (Tesis). Universitas Terbuka, Jakarta.

Humedi. (2017). Deskripsi Percakapan Pemahaman Konsep Matematis Siswa pada Pembelajaran Socrates Saintifik (Skripsi). Universitas Lampung, Bandarlampung.

Kilpatrick., Swafford., \& Findell. (2001). Adding It Up: Helping Children Learn Mathematics. Washington, DC: National Academy Press.

Krisna, F. \& Marga, M. (2017). Pemanfaatan Video Untuk Pembelajaran Matematika Berbasis Masalah Kontekstual pada Topik Aljabar. Prosiding Seminar Nasional Etnomatnesia (400-405). Yogyakarta, Indonesia: Universitas Sanata Dharma.

Lingga, M. (2016). Pengaruh Penggunaan Media Pembelajaran Quipper School Terhadap Hasil Belajar Siswa Kelas VIII Mata Pelajaran Matematika SMP Negeri 4 Semarang (Skripsi). Universitas Negeri Semarang, Semarang.

Miles. Huberman. \& Saldana. (2014). Qualitative Data Analysis A Methods Sourcebook, Third Edition. United States of America: Sage Publication.

National Council of Teacher of Mathematics. (2000). Principles and Standards for School Matematics. Reston, Va: NCTM.

Rohana. (2011). Pengaruh Pembelajaran Berbasis Masalah Terhadap Pemahaman Konsep Matematika Mahasiswa Prodi Pendidikan FKIP UPGRI Palembang. Prosiding Seminar Nasional Pendidikan (110-122). Palembang, Indonesia: Universitas PGRI Palembang.

Ruseffendi, E.T. (1988). Pengantar kepada membantu guru mengembangkan kompetensinya dalam pengajaran matematika untuk meningkatkan CBSA : perkembangan kompetensi guru. Bandung: Tarsito.

Saputra, M. \& Mujib. (2018). Efektivitas Model Flipped Classroom Menggunakan Video Pembelajaran Matematika terhadap Pemahaman Konsep. Desimal: Jurnal Matematika, 1(2). 173-179.

Stockley, D. (13 Mei 2014). E-Journey on E-Learning. http://www.derekstockley.com.au/eindex2b.html. Diakses pada tanggal 10 November 2018.

Wardhani, S. (2008). Analisis SI dan SKL Mata Pelajaran Matematika SMP/MTs Untuk Optimalisasi Pencapaian Tujuan. Yogyakarta: Pusat Pengembangan dan Pemberdayaan Pendidikan dan Tenaga Kependidikan Matematika. 